\title{
THE NEW PSEUDO-SUFI ORDER OF THE MAJELIS SHALAWAT AMONG URBAN MUSLIMS IN EAST JAVA \\ Rubaidi
}

UIN Sunan Ampel, Surabaya - Indonesia | rubaidi@uinsby.ac.id

\begin{abstract}
This article analyzes a new variant of urban Sufism with specific reference to majelis shalawat (shalawat group) as the new-pseudo Sufi order in Indonesia. It focuses on three majelis shalawat: Majelis Shalawat Kubro, Majelis Shalawat Muhammad, and Majelis Shalawat Adlimiyah. Employing field research, this article argues that the three shalawat groups that flourish in East Java have specific characters unique to the groups. They locate the silsilab (chain of lineage) as an important part in establishing the institution, doctrines, and Sufism practices among their adherents. The aspect of Sufism transmission is articulated as experiencing Sufism through living as inspired by Abu alQasim al-Junayd, not as told to them by 'ulama who theorize Sufism. Furthermore, doing Sufism means a process of experiencing supported by two Sufism traditions at once; they are vivid interconnection (räbitat bi al-suḅbah) and virtual interconnection (räbitab bi al-ghayb). The application of the two räbitabs locates a Sufi travellers in a full consciousness (yaqzah) far from self-disappearance (al-fan $\bar{a}, \overline{f i}$ al-shaykh). With all of its characteristics, the three shalawat groups generate new variants of Sufi practice that can be considered as new Sufi order.
\end{abstract}

Keywords: Majelis Shalawat, new Sufi order, urban Muslims.

\section{Introduction}

An interesting and new phenomenon has taken place in experimenting Sufism in urban areas of Indonesia. There is a vast growth of a new kind of Sufi brotherhood such as Majelis Shalawat Kubro, Majelis Shalawat Muhammad, and Majelis Shalawat Adlimiyah adhered by middle class groups in some cities in East Java, namely Surabaya, Bojonegoro, Sidoarjo, Pasuruan. The phenomenon of Majelis Shalawat is an important proof not only for the ever-increasing growth of urban Sufism or pseudo-Sufism, but also for the awakening 
of classical Sufism. This phenomenon is called the new pseudo-Sufi order. The rise is marked by the emergence of specific characters of Sufism as shared by three majelis shalawats (shalawat groups), which also differentiates them from similar groups studied by Howell, ${ }^{1}$ Zamhari, ${ }^{2}$ Zamhari and Howell, ${ }^{3}$ and Smith and $\mathrm{Hamdi}^{4}$ who popularize the terms of pseudo-Sufi order, neo-Sufism, pseudo-Islamic Sufism, pseudo-Sufi group, pseudo-Islamic sect, or pseudo-Sufi organization to denote this urban Sufism. The main difference lies in the key doctrinal aspect and its implementation. Therefore, the existence of these three shalawat groups cannot be any longer framed within the spectrum of the pseudo-Sufi order. Instead, it should be called as the new pseudoSufi order in the framework of urban Sufism.

Pseudo-Sufi order as studied by Howell and Zamhari ${ }^{5}$ is a terminological concept which is initially used to denote similar phenomenon in North America. The term is used to call an organization or group that teaches Sufi practices, but loosely adhering to general norms of a tariqah (Sufi order). In the United States, for instance, the term pseudo-Sufi order is used to come to terms with the transmission of an international Sufism movement led by Hazrat Inayat Khan (1882-1927 M). 6 The structure of its institution,

${ }^{1}$ Julia Day Howell, "Sufism and the Indonesian Islamic Revival," The Journal of Asian Studies 60, 3 (2001), 701-729.

2 Arif Zahmari, Rituals of Islamic Spirituality: A Study of Majlis Dhiker Groups in East Java, (Canberra: The Australian National University, 2010), p. 1.

${ }^{3}$ Arif Zamhari and Julia Day Howell, "Taking Sufism to the Streets: Majelis Zikir and Majelis Salawat as New Venues for Popular Islamic Piety in Indonesia," Review of Indonesian and Malaysian Affairs 46, 2 (2012), 47-75.

${ }^{4}$ Bianca J. Smith and Saipul Hamdi, "Between and Salafi Subjects: Female Leadership, Spiritual Power and Gender Matters in Lombok," Bianca J. Smith and Mark Woodward (eds), Gender and Power in Indonesian Islam, Leaders, Feminists, and Pesantren Selves (London: Routledge, 2017), 30.

5 Arif Zamhari, "Socio-Cultural Innovations in Urban Sufism, The Case Study of Majelis Dzikir and Shalawat Nurul Musthafa," Journal of Indonesian Islam 7, 1 (2013), 119-144; Zamhari and Howell, Taking Sufism to the Streets, 47-75.

${ }^{6}$ Elliot Bazzano and Marcia Hermansen, "Introduction," Elliot Bazzano and Marcia Hermansen (eds), Varieties of Sufism in America, Islam, Sufi Orders, and Authority in A Time of Transition (New York: State University of New York, 2020), 28; Patrick D. Bowen, History of Conversion to Islam in the United State, Vol. 1, (Leiden: Brill, 2015), 104-105; William Rory Dickson, Living Sufism in North America, Between Tradition and Transformation (New York: The State University of New York, 2015), 4; See also Garbi Schmidt, Islam in Urban America, Sunni Muslim in Cbicago (Philadelphia: The Temple University Press, 2004), 153. 
membership, and doctrine are the creation of Hazrat Inayat Khan. Among the major features of this movement is its specific and unique character compared to conventional Sufi orders. Similarly, many $d h i k r$ (spiritual chanting) and shalawat groups in Indonesia also show their distinct features. Among dhikr groups are Tanbihul Ghafilin, ${ }^{7}$ Majelis Dzikir and healing by Ustadz Hayono, ${ }^{8}$ followed by Ustadz Arifin Ilham's Majelis Dzikir Adz-Diikra, ${ }^{9}$ and Aa Gym's Manajemen Qalbu. ${ }^{10}$

Corresponding to the flourish of pseudo-Sufi order of dhikr and shalawat groups, three similar groups studied in this article emerge vastly. As a phenomenon of pseudo-Sufism, they attract a distinct membership of middle-class people from various backgrounds, namely businesspeople, academics, army and police officers, professionals, bureaucrats, and certainly religious clerics. Nonetheless, the emergence of these three groups does not necessarily represent merely pseudoSufi order phenomenon among urban people. The three groups still acknowledge the importance of silsilah or sanad (chain of lineage) that connect the chain of transmission for Sufism doctrine and practice from one generation to another by positioning wali mastur (hidden saint) at the top of its chain of lineage. The configuration of Sufism doctrine is also different from one majelis dhiker to another. The three majelis shalawats consistently position the doctrine of Abu al-Qasim Junayd of Baghdad as central. In addition, they hail Ibn 'Arabi as the key figure in guiding their adherents for becoming the perfect Sufi. This combination is certainly unthinkable among conventional Sufi orders. The reconstruction towards rabitah doctrine that connects between a Sufi traveler and his/her spiritual instructor is also another distinct feature.

\footnotetext{
${ }^{7}$ Arif Zahmari, Rituals of Islamic Spirituality: A Study of Majlis Dhiker Groups in East Java, (Canberra: The Australian National University, 2010), 14.

8 Ibid.

9 Ibid., 15-16; Julia Day Howell, "Indonesia's Salafist Sufis," Modern Asian Studies 44, 5 (2010), 1029-1051; Idem, Indonesia's Salafist Sufi (Singapore: S. Rajaratnam School of International Studies, 2009). Compare to Julia Day Howell, "Sufism on the Silver Screen: Indonesian Innovations in Islamic Televangelism," Journal of Indonesian Islam 2, 2 (2008), 225-239.

10 Julia Day Howell, “'Calling' and 'Training': Role Innovation and Religious Dedifferentiation in Commercialized Indonesian Islam," Journal of Contemporary Religion 28, 3 (2013), 401-419. Compare to Julia Day Howell, "Sufism and the Indonesian Islamic Revival," The Journal of Asian Studies 60, 3 (2001), 701-729.
} 
This article tries to analyze the development of the new phenomenon in Sufi order among Muslim urban community that refers to the concept of new pseudo-Sufi order. As the focus of study, three groups of shalawat are the subject of the study, namely Majelis Shalawat Kubro, Majelis Shalawat Muhammad, and Majelis Shalawat Adlimiyah that attract urban middle-class community in some cities in East java, namely Surabaya, Bojonegoro, Sidoarjo, and Pasuruan. With their distinct characters the three groups have, this article argues that the existence of this shalawat groups not only represents wide spectrum of pseudo-Sufi order, but also believes that they represent new prototype in the movement of urban Sufism that can be called as the new pseudo-Sufi order.

\section{Wali Mastur as the Initial Trigger of the Pseudo-Sufi Order}

One of the significant indications of the new pseudo-Sufi order that is embedded in Majelis Shalawat Kubro, Majelis Shalawat Muhammad, and Majelis Shalawat Adlimiyah is the importance of lineage (silsilab or sanad) in the institutional structure of the three groups. This is a sharp contrast with similar groups such as Majelis Shalawat Wahidiyah, ${ }^{11}$ Majelis Shalawat Nurul Musthafa, ${ }^{12}$ and Majelis Dzikir Dzikrul Ghafilin ${ }^{13}$ which tend to negate the lineage. Furthermore, those dhikr groups affiliated to Salafi and neo-modernist religious doctrines refuse the lineage because of their lack of such teaching from the prophet Muhammad. Therefore, these last groups insist that silsilab is a bid'ah (innovation) and therefore forbidden in Islam. ${ }^{14}$

The silsilah of Majelis Shalawat Kubro, Majelis Shalawat Muhammad, and Majelis Shalawat Adlimiyah take root very uniquely. Its emergence as the earliest in the genealogy of these three groups cannot be separated from the central figure of KH. Mohammad Tamyiz, and well-known among his followers as Mbah Tamyiz. For them, he is al-waliyy al-mastur (hidden saint). In addition, he is

11 Dewan Pimpinan Pusat Penyiaran Shalawat Wahidiyah, Profil Wabidiyah (Jombang: Dewan Pimpinan Pusat Penyiaran Shalawat Wahidiyah, n.d), 4-5; Sokhi Huda, Tasawnf Kultural, Fenomena Shalawat Wabidiyah (Yogyakarta: LKiS, 2008), xvi; Zahmari, Rituals of Islamic Spirituality, 115-124.

12 Zamhari, Socio-Cultural Innovations, 119-144; Zamhari and Howell, Taking Sufism to the Streets, 47-75.

13 Zahmari, Rituals of Islamic Spirituality, 207-212.

14 Ibid., 1. 
considered in the beginning of chain that connect dhiker or awräd (enchantments) from the Prophet Muhammad to the Sufis who practice it nowadays.

Tamyiz was born in Jombang, a small town in East Java about 70 kilometers west to Surabaya who lived and died in Surabaya (19191982). His significant role as Sufi master is hardly known among Muslims in the neighborhood. In daily life, he presented himself as common Muslim. There is no indication showing him as a saint. Furthermore, he was known as dukun (shaman). His saintship started to appear when some of his main disciples became the successor who spread shalawat groups by teaching Sufi doctrines of Junayd and Ibn Arabi at the same time. Through his successors, Tamyiz as a hidden saint was increasingly gaining justification and legitimacy. His existence as the hidden saint as well as at the top chain of lineage for three groups in classic Sufism tradition is emphasized by one of his successors, Kahar:

"In daily life, no one in his (Tamyiz) neighborhood believes that he is a saint, a holy man. You can imagine, I still remember how he lived. His appearance is like Sakera (common Madurese man). He wore black karate (baggy) pants up to his knees and wore Madurese red and white stripped T-shirt. Everyday we used to mingle with scavengers from whom he often bought the unsold trashes. The level of his saintship was started to reveal when he paid visit to local religious cleric that locals considered him as saint. For those who never escort him to the visit, it is not a surprise if he or she does not believe in his saintship". ${ }^{15}$

In the tradition of Sunni Sufism, common Muslims would not easily believe the saintship of Tamyiz. However, from the perspective of philosophical Sufism, especially Ibn Arabi, Tamyiz's saintship is not separated from the long process of Sufism history until now. By upholding the doctrine of "only himself and God witness his saintship", he becomes a small part of Malamatiyah Sufi. They are saints who reach the highest level, but intentionally hide themselves in many ways. Because of the height of Malamatiyah Sufi saints, Ibn Arabi once state "if the Malamatiyah Sufis show their saintship in front

\footnotetext{
15 Interview with Gus Kahar, Surabaya, September 9, 2014.
} 
of common people, they would venerate them as if they were God (law dhaharat makēanatahum min Allahi li al-näsi la al-ttakhadzühum älihatan)."16

Far before Tamyiz transformed the doctrine and practice of his Sufism and showcased in the form of shalawat, he wandered to learn Sufism from many saints in the region. As it is a commonplace among Sufis, the process is not only about physical contact, but also through spiritual session (barzakhi learning or Uwaysi learning). It is a unique and distinct transmission patterns that is practiced in Sufism tradition. This Barzakhi learning can be traced from the silsilab of dhiker or shalawat awräd that Tamyiz taught his disciples. Among the Sufi master is Shaykhana Khalil of Bangkalan. As emphasized by Kahar $^{17}$ and Mursyidin, 18 Shaykhana Khalil of Bangkalan is one of Tamyiz's master. ${ }^{19}$ After an intensive investigation, the tutelage between Shaykhana Khalil of Bangkalan and Tamyiz happened Barzakhi or Uwaysi (spiritual contact). It is because Shaykhana Khalil of Bangkalan passed away in 1927, whereas Tamyiz at the time was only 7 years old. ${ }^{20}$ Therefore, it is hard to believe that at that very early age Tamyiz had studied in Bangkalan. ${ }^{21}$

In addition to Barzakhi instruction with Shaykhana Khalil of Bangkalan, he also studied physically to reputable Sufi masters of his age. He was believed to have become the disciple of $\mathrm{KH}$ Hamid of Pasuruan and KH Romli Tamim of Darul Ulum Rejoso. He also

\footnotetext{
16 Abu Bakar Muhyiddin Muhammad bin Ali bin Muhammad bin Ahmad bin Abdullah al-Khatimi al-Ma'ruf bi Ibni Arabi, Al-Futubat al-Makkiyah (Beirut: Dar al-Fikr al-Arabi, 2011), 52.

${ }^{17}$ Quoted from the speech of Gus Kahar during pengajian (religious gathering) of Majelis Shalawat Muhammad in Sidoarjo, March 27, 2015.

${ }_{18}$ Gus Mursyidin is a pseudonym. He requested that his real name is not to be openly mentioned.

${ }^{19}$ Interview with Mursyidin, Bojonegoro, August 15, 2019.

${ }^{20}$ Mas'ud states that Shaikhona Khalil was born on Tuesday 11th of Jumadil Akhir $1235 \mathrm{H}$ (1819 CE) and die don 29th of Ramadhan $1343 \mathrm{H}$ (April $1925 \mathrm{CE})$ in Bangkalan, Madura. Abdurrahman Mas'ud, Dari Haramain ke Nusantara, Jejak. Arsitek Intelektual Pesantren (Jakarta: Penerbit Kencana, 2006), 184.

21 The communication between disciple and master of Shaykhana Khalil with his living disciple happened not only with Tamyiz. Shaykhana Khalil once also certified (grant ijazab) a Habib (a descedent of the the Prophet) in Sumenep to perform du'a barzakbi (Uwaysi). Rachman once said: "although he had passed away for years, Shaykhana Khalil certified ijazah barzakhi to Habib Muhsin Ali al-Hinduan who was still alive in Sumenep. The du'a was to repel disasters. See Saiful Rachman, Surat Kepada Anjing Hitam, Biografi dan Karomah Kiai Kholil (Jakarta: Pustaka Ciganjur, 2011), 68.
} 
studied to KH Usman of Sawah Pulo Surabaya who was also his close friend when studying to KH Romli Tamin of Jombang. ${ }^{22}$ Among his teachers include Habib Masrur Bawaqih, Curah Malang, Jombang, and KH Hamim Jazuli (Gus Mik), Ploso, Kediri. This latest figure was the teacher as well as disciple of Tamyiz. ${ }^{23}$

Tamyiz also studied under many prominent saints in the area of East Java to master Sufism. He studied under the tutelage of KH. Sahlan Tayyib of Pesantren Bahrul Ulum al-Sahlaniyyah, Sidorangu, Krian Sidoarjo from whom he studied Sufism as well as became his full servant. He always prepared praying mat for the master whenever he needed it to prayer. ${ }^{24} \mathrm{He}$ once studied under KH. Abu Bakar, Perak, Surabaya, Gus Thaha, and Abah Thayyib, Kemayoran, Surabaya. Both are Sufi masters in the region. He also studied in Gresik, adjacent to Surabaya where he learned Sufism to KH Sholeh, Pesantren Maskumambang, Bungah and KH Muhammad (Mbah Mad), Sedayu. He was also once a disciple of KH Ali Mas'ud (Mbah Ud), Pager Wojo Sidoarjo. In Pasuruan, he studied from KH Abu Amar, Payaman, Paserepan, in addition to $\mathrm{KH}$ Hamid. Other notable masters include

\footnotetext{
22 Interview with Bedjo, Bojonegoro, August 9, 2017.

${ }^{23}$ The shift of status between teacher and student in pesantren tradition as well as in Sufism tradition is normal. This situation once was experienced by Shaykhana Khalil of Bangkalan and KH. Hasyim Asy'ari of Jombang. Before departing to Mecca for further study and hajj pilgrimage, Kiai Hasyim Asy'ari was a student of Shaykhana Khalil. Upon returning from Mecca, he was very well-versed in (especially) hadith and later founded a pesantren in Tebuireng Jombang. His knowledge in hadith, which was still considered a new discipline by Javanese ulama necessitated Shaykhana Khalil to study hadith under tutelage of his former student in Tebuireng, especially during Ramadan month. From then on, the shift more frequently happened. See Mukani, Dinamika Pendidikan Islam (Malang Penerbit Madani, 2016), 127. Similar event also took place between Habib Shaleh Tanggul with KH Qusyairi who was the eldest son of KH Shiddiq Jember and the father in law of renown wali in Pasuruan, KH Abdul Hamid. Before this event, Habib Sholeh often attended the speech of KH. Qusyairi in Pasuruan. After years, Habib SHoleh shown the signs of being a saint (wali) so that $\mathrm{KH}$. Qusyairi increasingly attended the religious functions in which Habib Sholeh delivered his speech. The fact that KH Qusyairi was very accomplished ulama in term of knowledge and Sufism practice. The indication of his qualification was the request of Gus Mik (KH. Hamim Jazuli), the founder of majelis dhiker of Dzikr al-Ghafilin and a renown wali, to $\mathrm{KH}$ Qusyairi to review the awrad of the majelis before publicly implemented by its members. Compare with M.N. Ibad, Drikir Agung Para Wali Allah, Sejarah Penyusunan Drikrul Ghafilin dan Fadhilah Bacaan-Bacaannya (Bantul: Pustaka Pesantren, 2012), 57.
}

24 Interview with Mursyidin, Bojonegoro, August 15, 2019. 
Habib Sholeh, Tanggul Jember, Habib Husen, Asembagus Situbondo, $\mathrm{KH}$ Kusnan, Tumpang, Poncokusumo Malang, KH Ismail (Mbah Mail), Brangkal Mojokerto, Mbah Sholeh (custodian of graveyard of Troloyo site), Troloyo, Mojokerto, KH Ilyas, Karang Nongko Mojokerto, and KH Mohammad Farhan (Mbah Farhan), Perak Jombang, KH Makruf, Kedunglo Kediri, Gus Maksum Kediri, and Mbah Mundir Kediri. ${ }^{25}$

There are two forms of learning that Tamyiz performed with those living masters. Firstly, he studied as well as becoming servant for a lengthy period of time. In the process of studying, he served all of the masters wholeheartedly. Among the aforementioned masters, some of them were more inspiring than others. They were Syekhana Kholil of Bangkalan, KH Romli Tamim of Jombang, KH Sahlan Tayyib, Sidorangu, Krian, Sidoarjo, Abah Thoyyib, Kemayoran, and KH Abu Bakar, Perak, Surabaya. Secondly, he studied under a master with the purpose of tabarrukan (seeking for blessing). In so doing, Tamyiz visited a Sufi master and saint for blessing, Sufism advises and $d u^{\prime} a$ (supplication).

In addition to masters to whom Tamyiz studied in person, he also studied from the deceased saints of Java. Among the habit that he practiced for years is visiting graves of saints in many places from Surabaya, Trowulan site, Jombang, Kediri, Nganjuk, Bojonegoro, Tuban, Gresik, then back to Surabaya, and later on to Sidoarjo. He not only visited the graves of well-known saints like the Wali Sanga of Java, but also to graves of hidden saints not known to public. About this habit, Mursyidin explains: "In addition to visiting graves of $W$ ali Sanga, Tamyiz roamed around from one grave to another on foot. He visited many graves which I do not know whose graves they were. I just kept silent when escorting him visiting graves". ${ }^{26}$ In this Barzakhi spiritual journey, Tamyiz once claimed he studied under tutelage of Shaykh Siti Jenar who is known for the inclination toward Ibn Arabi's Sufism. This event was witnessed by Bedjo, one of his disciples who accompanied him in one of these journeys. Once Tamyiz said to Bedjo: "Didn't you see Shaykh Siti Jenar? He spoke to me just now. He sat near you and kept staring at you". ${ }^{27}$

\footnotetext{
25 Interview with Bedjo, Bojonegoro, August 12, 2019

26 Interview with Mursyidin, Pasuruan, August 12, 2019.

27 Interview with Bedjo, Bojonegoro, August 15, 2019.
} 
The trace of his spiritual journey becomes an important indication of this Barzakhi interaction which enables the transmission of Sufism knowledge from the deceased saint whose graves he visited. Kahar further emphasized that he too experienced similar event during his Sufi travels. He stated that the Barzakhi transmission of Sufi knowledge with the deceased saints would produce a deeper Sufi knowledge and its application compared to in person tutelage with living masters in the final Sufism journey until he achieved the level of hidden saint, Tamyiz started to transmitted Sufism doctrines and practices to his disciples. The well-known transmission pattern used among Sufis is through his speech, which in Javanese called as wejangan (statement of wisdom). This process is conducted to transmit high level Sufism doctrine and practice. Such a process once secretly conducted by Sunan Bonang to a novice, the aspiring Sunan Kalijaga. ${ }^{28}$

As a consequence of this mejang, the act of delivering wejangan by Tamyiz is the lack of actual record of his disciples. However, Kahar explains that Tamyiz had 9 disciples, 7 of which are of ethnic Chinese background. ${ }^{29}$ One of those 7 disciples is Syamsu Duha (1956-2004) who is the heir that founded Majelis Shalawat Kubro and later became its murshid (Sufi master). Among thousands of Syamsu Duha's disciples, it was Kahar (1962-2015) who succeeded Syamsu Duha as the spiritual leader of Majelis Shalawat Kubro. After him, Mursyidin (b. 1972) as a disciple of Kahar as well as Syamsu Duha leads Majelis Shalawat Kubro, Shalawat Muhammad, and later founded Majelis Shalawat Adlimiyah.

\footnotetext{
28 The event of amejang (delivering special instruction) as mentioned was about the story of a controversial Sufi mystic of Java, Shaykh Siti Jenar. The story was mentioned in several literature discussion the mysticism of Javanese Islam, like in Falsafah Siti Djenar authored by Bratakesawa (1954), the manuscript of this literature is kept in Radyapustaka Museum entitled Seh Siti Jenar R. the story is also told in Serat Sitijenar. In Falsafah Siti Djenar, it was narrated: "nalika Sunan Benang mejang iktikad dhateng Sunan Kalijaga wonten setengabing baita, baitanipun rembes. Baito wau lajeng dipun popok mawi endhut, dilalah endhutipun katutan elur (cacing alit). Amilo pun elur saget mireng wejangan wau sedoyo, lajeng nguwub satataning jalma. Wasana dipun sabda dening Sunan Bonang: dados jalmo, serta kasukanan nama Seh Siti Jenar, tuwin sinengkakaken saking ngandap ing ngalurub: dados wali." See Sujamto, Reorientasi dan Revitalisasi Pandangan Hidup Jawa (Semarang: Dhahara Press, 2000), 86.

${ }^{29}$ Another two disciples are Javanese origin. They are Muhammad Munir who is the father of Kahar, and the other is Rahman who is the father of Mursyidin. Interview with Kahar, Surabaya, July 23, 2015.
} 
One important note is that both Kahar and Mursyidin never studied under the tutelage of Tamyiz in person. The position of Kahar as murshid was a result of guidance of Syamsu Duha as his master. Meanwhile, Mursyidin is a son of Rahman (d. 1997), a disciple of Tamyiz. Therefore, Mursyidin were spiritually guided by two masters; Syamsu Duha and Kahar. Thus, it can be sated that the position of Mursyidin as a Sufi master and the successor of Tamyiz Sufism doctrine and practice is very authoritative.

\section{The Reference to Lelaku as a Practice of the Pseudo-Sufi Order}

There is a Sufism tradition that is attached to three shalawat groups that is very distinctive compared to similar groups, dhikr groups even to orthodox Sufi order. Sufism articulation is very strong in these three groups. A Sufi master should be strongly and strictly anchored in the tradition of Sunni Sufism as taught by imam Junayd of Baghdad. In Indonesian Sufism tradition, his name is the ultimate reference in establishing and practicing Sufism, especially for orthodox Sufi orders. This established tradition is apparent in the three shalawat groups. This statement can be traced from the process of Sufism guiding selection of disciples so that they achieve the position of murshid. In the process of spiritual training of disciples by Sufi master, the doctrine of Junayd of Baghdad is always the point of reference.

The position of Junayd of Baghdadi as a main reference for the practice of urban Sufism with its strict rules in these three shalawat groups is indeed very distinctive. For instance, Shalawat Wahidiyah puts more emphasis on Sufism practice that refers to general Sufism doctrines, such as the stages of ascendancy of Sufism travel (maqam) that is transmitted during the process of mujahadah (earnest striving for Sufism journey). ${ }^{30}$ Likewise, Majelis Nurul Mustafa also only emphasizes on universal ethic that is inspired from the Prophet Muhammad's deeds as the main doctrine for transmission trough study groups or other means, like website and recordings. In study groups run by Salafi Muslims, the doctrines circulated through study groups, intensive

\footnotetext{
${ }^{30}$ In Majelis Shalawat Wahidiyah there is a well-known Sufism doctrine that every practitioner who wish to wusul (unite with God) would experience steps of syukur (gratitude), ikblas (sincerity), sabar (patience), ridha (satisfaction), tawakkal (trust in God), mahabbah (love), and positive prejudices or busn al-dzan (good presupposition). See Dewan Pimpinan Pusat Penyiar Shalawat Wahidiyah, Kuliah Wabidiyah (Jombang: Dewan Pimpinan Pusat Penyiar Shalawat Wahidiyah, 2005), 182-2015.
} 
course, website, ${ }^{31} \mathrm{DVD}$, and seminars are very general, namely all doctrines dealing with positive Sufism. ${ }^{32}$ The distinction on the selection of Sufism doctrines and the difference of the method of tutelage indicate that the three shalawat groups are no longer aptly identified as urban Sufism or pseudo-Sufi order. Instead, they are now a new pseudo-Sufi order.

One doctrine that is distinct to Junayd of Baghdad is the method of Sufism venture that should be always in accordance with Sunni Sufism (orthodoxy). About this doctrine of Sufism ethic, al-Baghdadi as reported by al-Qushayri, asserted that Sufism journey should not follow what people said, but the experience of hunger, leaving the world behind, and abandoning hedonist and glamorous way of life. ${ }^{33}$ Al-Ansari, a commentator to al-Qushayri's al-Risālah further highlights this point by saying:

"...(what imam al-Junayd) is clearly understandable because Sufism according to many Sufis is essentially a statement of how a person act in accordance to the best ethic, by distancing oneself from haram and undetermined of its lawfulness, not enslaved by worldly lures, trust in God (tawakkul), satisfaction (rida) of God's destiny, and so forth. At the same time, a Sufi traveler should avoid bad characters such as showing off, arrogance, envy, and so on. Practicing Sufism is not about talking and quoting words of wisdom of great Sufis. ${ }^{34}$

31 The choice of Sufism doctrine of Majelis Nurul Musthafa can be traced from the reference it uses. There are at least two important references in building universal ethic of the followers, namely: Khasha'ish al-Ummah al-Muhammadiyah by al-Sayyid Muhammad ibn 'Alawi al-Maliki al-Hasani, and Al-Nasha'ih al-Diniyyah wa Washaya alImaniyah authored by Abdullah Alawi al-Haddad. Zamhari, "Socio-Cultural Innovations in Urban Sufism, 142; Zamhari and Howell, Taking Sufism to the Streets, 60.

32 Howell, Sufism and the Indonesian Islamic Revival, 721.

33 The text says: "I heard Al-Shaykh Abu Abdurrahman al-Sulami may Allah have mercy upon him, once said: I heard Muhammad ibn Abd Allah al-Razi once said: I heard Abu Muhammad al-Jariri once said: I heard Shaykh al_Junayd said: we practice Sufism not based on what people have said. We practice Sufism by experiencing hunger, renunciation, and abandement of hedonism and glamor. See Abu al-Qasim Abd al-Karim ibn Hawazan al-Qushayri, Al-Risalah al-Qushairiyah (Beirut: Dar al-Kutub al-Ilmiyah, 2001), 50. See also Musthafa al-Arusi, Hashiyah al-'Allamah Musthafa al-Arusi al-Musamma Nata'ij al-Ifkear al-Qudsiyyah fi Bayan Ma'ani Sharkh al-Risalah al-Qushairiyah, Vol. 1 (Beirut: Dar al-Kutub al-Ilmiyyah, 2007), 218.

34 Abu Yahya Zakariyya Ibnu Muhammad al-Anshari, Ibkam al-Dilalab 'ala Tabrir alRisalah al-Qusiariyyah, Vol. 1 (Damascus: Dar al-Nu'man li al-Ulum, 2000), 148-149. 
This basis of al-Baghdadi teaching becomes the distinctive feature as well as the fundamental doctrine of Tamyiz's Sufism. Later on, this fundamental Sufism perpetuates and forms spiritual genealogy in Syamsu, Kahar and Mursyidin which is eventually adhered by the network of their followers that spread in many cities across Indonesia and abroad. Being a Sufi means a substantial action ('amaliyab), not theoretical in nature (nazariyab) nor intellectual (ilmiyab). The totality of Sufism in this way in classic Sufism terminology is identical with the term lelaku or tirakat in Javanese tradition or riyadhah in Arabic term, which denotes spiritual strive of Sufism.

The practice of urban Sufism in these three shalawat groups are also distinct from other similar groups and Sufi orders for other reason. This argument is important to be born in mind since there are so numerous groups that similar if not identical in Indonesia, urban or rural areas. For instance, Majelis Dzikrul Ghofilin of the late Gus Miek (KH Hamim Jazuli) and Majelis Shalawat Wahidiyah by the Late Gus Majid did not present smooth succession process during the transfer of authority from a Sufi master to another. In contrast, Tamyiz relegated his authority to next successors up to four generation without interruption until today.

The lelaku system in the three groups of shalawat is also different from other shalawat groups. The phenomenon of the emergence of Majelis Shalawat Nurul Mustofa led by Habib Hasan bin Ja'far Assegaf and Majelis Rasulullah of Habib Munzir al-Musawwa is identical to these three groups of shalawat. As a phenomenon of urban Sufism that fill the empty spiritual space of urban middle-class people in Jakarta, both adhere the line of Sunni Sufism. Both leaders of the shalawat groups is not yet analyzed from the perspective of genealogy because there is not yet a process of succession in the groups, although both could originate from a type of Sufism that use lelaku system in spiritual journey. Nonetheless, according to Zamhari, the two groups seem to be loose in terms of disciple-master relationship. ${ }^{35}$ There is not strong bond between master and disciple in comparison to Sufism tradition in Sufi order in general. In these two shalawat groups, urban middle-class people generally are only tied by periodical shalawa $\bar{a}^{-}$sessions of the groups. Outside the sessions, they are free to perform other spiritual activities. This fact is supported by their freedom to choose and

35 Zamhari, Socio-structural Innovations in Indonesia's, 134-135. 
participate in various dhikr and/or shalawat groups other than the two groups.

The argument on the key word of lelaku in three shalawat groups is also different from numerous dhikr groups of urban Sufism, especially Sufism from the lane of Islamic revival, neo-modernist, of Salafi. This kind of Sufism can be referred to some institutions like ICNIS (Intensive Course Networking for Islamic Sciences), IIMaN, which were initiated by some prominent Muslim modernists like Nurcholish Madjid and Haidar Bagir. In addition, there are also some urban Sufism groups like Manajemen Qolbu led by Aa Gym, Majelis Dzikir al-Dikra of Ustadz Arifin Ilham, and Penyembuhan Hati of Ustadz Haryono. The existence of various urban Sufism groups is actually a counterattack or critique toward orthodox Sufism, especially tariqah. Therefore, in Indonesian context, the basis of Sufism takes the spirit of Hamka's thought in his book "Sufisme Modern". ${ }^{36}$ In addition, for urban Sufism of neo-Salafi, the practice of orthodox Sufism remains a bid'ah (innovation), khuräfah (superstition), and syncretic. The main reason for this accusation is the lack of injunction in the Quran and precedence from the Prophet Muhammad. Although the debate is superficial, various Sufism practices of the two approaches are conducted in offices, malls, mosques, Islamic study groups, and even television. They act as a media for introspection. ${ }^{37}$ The borderline that demarcates the orthodox Sufism and urban Sufism is their attribution as "neo-sufi," "positive sufism," and "practical sufism. ${ }^{38}$

For neo-Sufism, the existence of Sufism doctrine in fulfilling new space of urban community is unavoidable. However, some doctrines of orthodox Sufism remain unacceptable for those urban people. In addition to the doctrine of unity of being (wihdat al-wujud), the master veneration is other example of orthodox Sufism that is unacceptable. About this Sufism practice, neo-modernist Muslims call it as "Islam but not Islam." 39 Those two aspects are the point of distinction

\footnotetext{
${ }^{36}$ Howell, Sufism and the Indonesian Islamic Revival, 719.

37 Wasisto Raharjo Jati, "Sufisme Urban di Perkotaan: Konstruksi Keimanan Baru Kelas Menengah Muslim,” Jurnal Kajian \& Pengembangan Managemen Dakwah 5, 2 (2015), 179-180.

38 Howell, Sufism and the Indonesian Islamic Revival, 722.

39 Julia Day Howell, "Modernity and Islamic Spirituality in Indonesia's New Sufi Networks," Martin Van Bruinessen and Julia Day Howell (eds), Sufism and The 'Modern' in Islam (New York: I.B.Tauris, 2007), 219.
} 
between urban Sufism associated with Sunni Sufism and urban neomodernist Sufism. To replace these two doctrines, Nurcholish Madjid, the spokesperson of neo-Sufism, reformed orthodox Sufism with rationality approach. In his mind, Sufism in form of tariqab is no longer relevant in actualizing Islam in modern life. Meanwhile, in IIMaN, Haidar Bagir rationalizes Sufism practices by emphasizing the achievement the dimension of peace and happiness. ${ }^{40}$ As a consequence of Sufism rationalization among urban Sufism of neomodernists, the massive transformation of Sufism doctrine utilizes television in conveying their tawsiyab (guidance). Thus, it is identical to televangelism. ${ }^{41}$

In contrast, the transformation of urban Sufism in three shalawat groups remains conventional. They employ cultural media, such as sessions of shalawat groups in delivering their Sufism doctrines. The session is usually held periodically, either in the house of the master or the houses of disciples. However, other media is also utilized, like the neo-modernists do. In the final years of his life, Kahar also appeared in local TV station, namely TV9, in a program named "kembang tawasuf" as a means to communicate his Sufism to wider audience. ${ }^{42}$ In addition, as an important fact on justifying urban Sufism in the three groups of shalawat is the employment of media that corresponds to symbol of urban middle class people. Since Syamsu up until the next two Sufi masters, the groups adapted to the identity of urban middleclass people. Some sessions even were held in hotels, malls, cafes, and restaurants. In each place, they gather and form study clubs. They conduct this spiritual session often with food and drink served on the table. The three murshids of different era opened various dimension of Sufism to disciples with certain limits.

\footnotetext{
40 Jati, Sufisme Urban di Perkotaan, 190.

${ }^{41}$ This fact refers to televangelist preachers in spreading the teaching of urban Sufism or political ideas by utilizing TV stations which are massively accessible by urban as well as rural people. To mention some names, there are Aa Gym, Arifin Ilham, Haryono, Jefry al-Buchory, Mamah Dedeh, and Qurrata A'yun. See Akh. Muzakki, Islamic Televangelism in Changing Indonesia: Transmission, Authority, and The Politic of Ideas (Singapore: ISEAS, 2012), 45-46.

42 For some episodes, the Pengajian of Majelis Shalawat Muhammad was broadcasted in a program entitled "Kembang Tasawuf" in TV9, a TV station affiliated to Nahdlatul Ulama of East Java. In addition, the recordings of this program were uploaded to Youtube with a total of 12 episodes. To research and listen the Sufism thought of Gus Kahar, youtube content is still available by typing key word of kembang tasawnf.
} 
Urban Sufism as represented by three shalawat groups as described becomes the distinctive character compared to various dhikr groups, shalawat groups, and tariqah. The interaction between Sufi masters and their disciples is not limited to various places associated with urban middle-class people. Other symbol of middle-high class such as luxury cars, branded clothing, and various accessories are embodied in shalawat community. However, although adapting to these worldly symbols, there is no bargain with fundamental doctrine of Sufism in form of lelaku. It means that the master-disciple relation, be it within shalawat groups or in public space, even in working place and at home remains bound to the lelaku.

Fundamental Sufism in the form of lelaku as taught by Junayd of Baghdad becomes inherent part of the ideology of Sunni Sufism. The primary references of the ideology include Ayyuba al-Walad by alGhazali, ${ }^{43}$ "ta 'Tim al-Muta'allim" by al-Zarnuji, ${ }^{44}$ and Adab al- ATlim wa alMuta'allim by KH Hasyim Asy'ari. ${ }^{45}$. These treatises become ethical code for students of pesantren in many regions in Indonesia. The strong relationship between master and students in pesantren and tariqah finds its justification in those treatises. Although only consisting of 23 pages, al-Ghazai's Ayyuha al-Walad becomes the code of conduct in the lelaku of the three shalawat groups. Syamsu and Kahar acknowledged the spiritual depth of this treatise. In addition, Mursyidin asserted that this treatise is specifically intended for those who start their spiritual journey in Sufi path. ${ }^{46}$

Finally, lelak $u$ becomes the most important part in the genealogy of three shalawat groups. One of lelaku manifestation is when the master intentionally says something not true about one of his disciples. Kahar once said remembering his own experience: "Do not say you study under a Sufi master before your master says something not true about you and your rights are taken away by your master." ${ }^{77}$ Mursyidin also

\footnotetext{
43 Abu Hamid al-Ghazali, Ayyuha al-Walad finasihat al-Muta'allimin wa Mawidatibim li Ya'lam wa Yumayyiz. 'Tlman Nafi'an (Singapore: al-Haramain, 2005).

${ }^{44}$ Burhan al-Islam al-Zarnuji, Ta'lim al-Muta'allim: Țariq al-Ta'lim (Beirut: Darul Ihya' alKutub al-'Arabiyah, n.d.).

${ }^{45} \mathrm{KH}$ Hasyim Asy'ari, Adab al-Alim wa al-Muta'allim fi ma Yabtaj Ilaibi al-Muta'allim fi Ihwali al-Ta'lim wa ma Yawaqqafu Ilaibi (Jombang: Maktabah al-Turast al-Islami, 1938).

46 Interview with Gus Mursyidin, Pasuruan, April 11, 2020.

${ }^{47}$ Quoted from the words of Gus Kahar in a session of Pengajian Majelis Shalawat Muhammad, Sidoarjo, 13 March 2015.
} 
once said recollecting his spiritual journey: "My two beloved masters occasionally ordered me to do opposite things. That was a true challenge that sometimes made me want to scream." 48

One important note is that all lelaku actions are performed without prior explanation by Sufi master. The ethic between murshid and murid (disciple) is itself an important doctrine in tariqah. It is fully realized by the three murshids in three shalawat groups. When performing lelaku during their spiritual journey, they performed all of the teachers' orders with no question being asked. ${ }^{49}$ For the three murshids, a murid is a dead person in front of murshid (or al-murid ka al-mayyit). With similar expression, all tariqah acknowledge and considered lelak $u$ as a doctrine to establish the obedience of disciples in front of their Sufi masters, although these three shalawat groups are not formally a tariqah.

\section{Practicing the Pseudo-Sufi Order Through Räbitah}

Rábitab in the tradition of classic Sufism simply means an endeavor of a disciple to present and visualize his or her Sufi master in all of his or her action. ${ }^{50} \mathrm{Al}-$ Kurdi formulates a more subtle definition of räbitah as an effort to bring the soul in harmony with the master's soul, although they do not physically meet in person. ${ }^{51}$ The meaning of physical visualization refers to a condition in which a disciple always makes his or her master present even though not in flesh and blood. Rábitah is an important method in the process of transmission of knowledge from a Sufi master to disciples. In contrast to other science that can be obtained through an autodidact manner, Sufi travelers are required to advance delicate and complex stages (maqämäh) along the

\footnotetext{
48 Quoted from the words of Gus Mursyidin in a session of Pengajian Majelis Shalawat Adlimiyah Gus Mursyidin, Bojonegoro, August 15, 2017.

49 There should be no effort whatsoever to critically question or challenge the instruction of lelaku tirakat from the murshid. Ibn Hajar al-Haytami said this centuries ago. In one of his works he said: if a disciple asks even with short words, for instance, "for what?" lelaku should be performed, and it would ascertain that the whole process of spiritual journey is a failure. He further said: "whoever ask his or her shaykh the purpose of the action he or she will not succeed forever. He or she would fail in the process of spiritual journey" (man qala li syaikhi lima? Lam yasluh abadan: ay li syaikhi fi alsuluk wa al-tarbiyah). See Ahmad Shihab al-Din bin Hajar al-Haytami al-Makki, al-Fatawa al-Hadithiyah (Beirut: Dar al-Fikr, 2013), 77.

50 Abdul Malik, "Institusi Persaudaraan Sufi," El-Harakab 8, 3 (2006), 358.

51 Muhammad Amin al-Kurdi al-Irbili Ibnu al-Syaikh Fathullah, Tanwir al-Qulub fi Mu'alati Allamu al-Gbuyub (Damascus: Mathaba'ah al-Shabah, 1994), 444.
} 
path to their goal. Therefore, a novice would take a director $24 / 7$ to lead him or her. The director or Sufi master (murshid or shaykh) should be a person with matured experience and profound knowledge who has achieved the level (maqam) of saintship (by gnosis ma'rifah). The goal of a disciple in the last phase is no other than meeting the Prophet and wusulul (directly linked) to God (ma'rifah). For this reason, the dictum al-murid ka al-mayyit in classic Sufism becomes relevant.

The concept of rabitah might be alien to urban Sufism or pseudo Sufi order from neo-Sufism of neo-Salafi. It is an important aspect for classic Sufism, however, that modernist Muslims object. It is comprehensible that many urban Sufism groups with neo-modernist inclination refuses this rabitah concept. For this reason, räbitah is the heart of debate, and therefore the point of distinction between urban Sufism of neo-modernist and Salafi in one hand and traditional Sufism in the other. As a result, many dbikr and shalawat groups in the context of urban Sufism do not understand, let alone apply, this rabitah concept. In contrast, rabitah is not a new discourse among tariqah disciples. Similarly, the concept of tariqah in the three groups of shalawat is important and it becomes a distinctive identity for them as a new Sufi-order.

Since urban Sufism does not implement räbitah, they further consider it as bid'ah, kburäfah, even pantheistic and therefore unorthodox. In addition, the spirit of urban Sufism is actually a continuation of Islamic renewal, for which classic Sufism, because of its innovations, is a target of this renewal. In wider spectrum, institutional network and the doctrine of neo-Sufism cannot be separated from Nurcholish Madjid and Paramadina foundation..$^{52}$ They instigated the emergence of various modern Sufism institution in urban context, like Jakarta and some other big cities in Indonesia. As a revision of tariqah-based Sufism, Nurcholish Madjid or other big names of urban Sufism developed Sufism doctrines that are suitable with modern demands. The key word that Nurcholish Madjid

\footnotetext{
52 As part of Islamic renewal, urban Sufism was developed and spread by neo-Sufism circles in many urban areas in Indonesia. Nurcholish Madjid is an important personality of this renewal movement of neo-modernism groups. Sufism dimension eventually became a target of this renewal movement. As a neo-Sufism figure, Nurcholish Madjid, through Paramadina foundation, lied basis of urban Sufism doctrine as well as envisaged its network using Islamic modernism persuasion. See Howell, Sufism and The Indonesian, 720-722.
} 
emphasized was rationalization, the word that connect Islam with modernism. 53

The debate about räbitah among urban Sufism creates new concept as revision of classic Sufism. For classic Sufism, räbitah is understood as spiritual bond between disciple and director. In contrast, urban Sufism positions räbitah as a mere solution-based bond as well as the fulfillment of spiritual need between jama' $a b$ (congregation) and ustä $d h$ (teacher). ${ }^{54}$ Therefore, the bond in urban Sufism is not hierarchical, compared to what happens in tariqah. Instead of räbitah, urban Sufism emphasizes on education and discussion with the spirit of purification. This phenomenon can be seen in groups of usroh and halaqah in some campuses which are run by Salafi Muslims, or known as ikhwä. This Ikhwan Sufism in Indonesia is inspired by al-Ikhwan al-Muslimun's Hasan al-Banna that recognizes the term murshid, ikhwān and wazifah. The formation of campus-based Sufism ideology eventually gave birth to its political wing of Partai Keadilan. ${ }^{55}$ Outside Ikhwan Sufism are some groups, such as Paramadina, ICNIS, and IIMaN which choose to focus on intellectual discussion, instead of political activity. Beyond them, there are still groups of urban Sufism that utilize dhiker or tawsiyah (sermons) using television broadcast as media. It is not a surprise that the presence of televangelist $u s t a \bar{d} h$ gain popularity among urban audience.

Different from Sufism practice among neo-modernist, räbitah is perceived as a necessity for mystical advancement for tariqah followers. The process of bringing the soul in harmony with the master's soul or physical visualization of the director is an important ingredient in gaining masters' guidance (yastabdhiru al-murid shürata syaikhibi 'ala akmali al-aḅwāi li yahshula lahu al-madād). ${ }^{56}$ For a disciple, räbitah is a gate as well as intermediary in achieving the ultimate stage in mystical journey. Based on this argument, räbitah in classic Sufism can be described as follows: "Describing the picture of the shaykh in a disciple's imagination, bringing the soul in harmony with the shaykh's

\footnotetext{
${ }^{53}$ Jati, Sufisme Urban di Perkotaan, 190.

${ }^{54}$ Ibid., 179.

55 Yon Machmudi, Islamizing Indonesia: The Rise of Jamaah Tarbiyah and Prosperous Justice (PKS) (Canberra: ANU Press, 2008), 139.

${ }^{56}$ Darniqah, al-Thariqah al-Naqsyabandiyah wa A'lamub (Libya: Mathba'ah Jarus Bar, 1987), 28.
} 
soul, although they do not physically meet in person. The disciple should imagine the soul of the shaykh as the ocean of spiritual gift, and thereof poured into the disciple's soul." 57

In a different gradation to tariqah, the three Majelis Shalawat Kubro, Shalawat Muhammad, and Shalawat Adlimiyah, position rabitah as the key concept in master-disciple relationship. Generically speaking, rabitab concept consists of two categories, namely; (1) direct connectedness (räbitah bi al-suhbah), and virtual visualization (räbitah bi al-ghayb). ${ }^{58}$ Rábitah bi al-suḅbah usually conducted during the early years of spiritual journey through certain lelaku tirakat. If a murshid believes that his disciple accumulates the ability to perform independently, then rabitat bi al-ghayb will be applied. The practice of rabitah is performed under very strict rule, especially for select disciples. For a disciple, rabitah practice will lead him or her to relate with the guidance of the murshid to meet the Prophet Muhammad. After meeting with the prophet, a disciple will advance to the next stage, wus ūl to God (the union of the aspirant with God). ${ }^{59}$

57 Van Bruinessen, Tarekat Naqsyabandiyah, 83. Van Bruinessen apparently quotes alKurdi's treatise entitled Tanwir al-Qulub fi Mu'alati Allamu al-Ghuyub, a treatise on Sufism very popular among tariqah and pesantren in Indonesia. In addition to rabitat almurshid, al-Kurdi adds a method of sufi travel through rabitat al-qubr of visualization of grave as a series of muqaddimah min al-muqaddimat al-diiker (introduction for dhiker or litany). Muhammad Amin al-Kurdi al-Irbili Ibnu al-Syaikh Fathullah, Tanwir al-Qulub $f i$ Mu'alati Allamu al-Ghuyub (Damascus: Mathaba'ah al-Shabah, 1994), 576.

58 The term subbah has basic meaning, which is "commune in the same place and time" (al-mu'ashara). In Sufism tradition, this term is known as an important doctrine to deliver disciples to the goal of spiritual journey. Rabitat al-subbab is actually not recognized among sufi orders. Instead, it becomes a distinct doctrine of these three majelis shalawats. Rabitat doctrine is related to subbab indicates the importance of the connection between disciple's soul with his or her Sufi master, in the context of the physical presence of the shaykh. Rabitat fi al-subbah does not merely indicate the meeting of the two persons, but marks the process of trust and love to the shaykh which eventually arouses spiritual motivation that all the shaykh's instruction is an obligation which has to be performed. The consequence is that criticism, complaint, argument and other things that undermine the merit of obedience to shaykh is absolutely absent from the disciple's soul. Compare to Abdul Wahhab al-Sya'rani, $A l$ Anwar fi Adabi al-Shubbab inda al-Akbyar (Damascus: Maktabah Abu Ayyub al-Anshari, 2007), 27-28.

${ }^{59}$ Syeikh al-Khalid al-Naqsyabandi, "Risalah ila Khulafa'ihi fi Istanbul li Bayani Ma'na al-Rabithah al-Naqsyabandiyah," Nazar Abadzah (ed.), Al-Shaykeh al-Khalid alNaqsyabandi, Al-Alim al-Mujaddid, Hayatubu wa Abammu Mu'allafatibi (Libanon: Dar alFikr al-Mu'ashir, 1994), 24-29; Muhammad Abdul Badiyyah, Al-Naqsyabandiyah, 
Interestingly, the second practice of räbitah, räbitat bi al-ghayb is implemented in many ways. It depends on the master's whish. It can be in form of recollecting wird, dhikr, riyadlah (spiritual exercise) to the graves of saints, manual labor, and other unthinkable activities. On the last point, Kahar's experience was very peculiar. When he was still a novice, his director asked him to accompany him going to cinemas. At a time, he explained: I was instructed how to conduct wird sirri (secret enchantment). While I was watching movies, I should not stop chanting the wird. After long practice, even though I watched movies, I only witnessed my murshid. ${ }^{60}$ On the other hand, in addition to performing räbitat bi al-ghayb in the form of wird, dbikr, and riyadlah in the graves of many saints, Mursyidin was also commanded by his murshid to work in prostitution localization area in Tretes, near Pasuruan. In the context of harmonizing souls with the murshid, Mursyidin said:

"One of my murshid's instruction was to work in a place located near to prostitution area in Tretes. You can imagine that many things that took place there contrary to my consciousness. I cried a lot because what I saw was contrary to my conviction. Amidst this situation, I constantly recollected my directors. I did not care, whether I had become apostate as a result. I just recollected my murshid. By recollecting my murshid, finally I managed to survive in that job e few years until he instructed me to quit". ${ }^{61}$

Rabitab practice in the tradition of classic Sufism also closely related to the concept of fana (dissolving individual self into Universal Being) in the teaching of Junayd of Baghdad, Abu Yazid of Bistam (Bayazid), and Ibn Arabi. The concept of fana is an embryo of the teaching of union with God (either ittihäd or waḥdah al-wujüd). Fanā can be articulated as the transformation of humanly attributes to divine attributes. ${ }^{62}$ According to Kahar as well as Mursyidin, before a disciple reaches fan $\overline{\text { to }}$ God (fana bi Allab), he or she should be in the state of

Nasy'atuha wa Tathawnuruba Lada al-Turk (Egypt: Dar al-Tsaqafiyah li al-Nasyar, 2010), 78-83. Compare to Muhammad al-Khani al-Khalidi, Al-Sa'adah al-Abadiyah fima Ja'a bibi al-Naqsyabandiyah (Istanbul: Maktabah al-Haqiqah, 2012), 12.

${ }^{60}$ Interview with Kahar, Surabaya, June 17, 2015.

${ }^{61}$ Interview with Mursyidin, Pasuruan, May 9, 2020.

${ }^{62}$ Rahmawati, "Memahami Ajaran Fana', Baqa', dan Ittihad dalam Tasawuf," AlMunzir 7, 2 (2014), p. 74. 
fana with the master (fana bi al-shaykh). This argument is constructed upon the notion that a Sufi traveler cannot experience fana bi Allah before truly in conviction of his or her murshid. This conviction will lead a disciple to experience fana in the shaykh. Only after this process, a disciple continues to experience fan $\bar{a}$ to God with the mediation of the shaykh. Therefore, for three shalawat groups, räbitah is closely related to fan $\bar{a}$ station.

The doctrine of fana bi al-shaykh in these three shalawat groups is legitimized in many classic Sufism treatises. One doctrine that is renowned in classic Sufism is the degree of rabitab determines the ascent of a disciple in achieving the ultimate goal of spiritual journey. The deeper and more disposed a disciple in experiencing fan $\bar{a}^{-}$in shaykh, the more likely he or she experience dissolution in God (fana $f i$ Allah). ${ }^{63}$ The connectedness of disciples to the shaykh in three shalawat groups materializes in normal condition, even when a disciple performs the shaykh's instruction. The rationale about relationship between the concept of fan $\bar{a}$ and rabitah reinforces the existence of there shalawat groups as more than just a mere urban Sufism or pseudo-Sufism. Instead, the practice of urban Sufism in the three shalawat groups emphasizes the harmonization of classic Sufism and modern culture. It is this point that Majelis Shalawat Kubro, Majelis Shalawat Muhammad, and Majelis Shalawat Adlimiyah is aptly justified as the the new pseudo-Sufi order.

\section{Conclusion}

The discussion on Majelis Shalawat Kubro, Majelis Shalawat Muhammad, and Majelis Shalawat Adlimiyah shows that variants of local Sufism among urban middle class is more than just pseudo-Sufi order. The three majelis shalawats can be considered as new pseudo-Sufi orders. This novelty is characterized by several key points. This new pseudo-Sufi order is marked by the importance of silsilah or sanad

${ }^{63}$ Mulyati, Peran Edukasi Tarekat, 377; Darniqah, al-Thariqah al-Naqsyabandiyah, 35. The self-annihilation in rabithah refers to Ibn al-Abbas dream of meeting with the Prophet. Amidst the dram, some of the Prophet's wives (ba'dbu ummahä al-mu'minin) appeared, and gave the mirror of the Prophet to Ibn al-Abbas. When he saw the mirror, what he actually saw was the face of the Prophet, while his face is non-existent (ra'a shurah alNabi wa lam yara shurata nafsibi). Among the Sufis, "badza buwa al-fana' fi al-rabithab", the event that Ibn al-Abbas experienced is called as annihilation in rabitah. Rafiq al-Ajam, Mu'jam Musthalahat al-Tashawnuf al-Islami (Beirut: Maktabah Lubnan Nasyirun, 1999), 739. 
(genealogical lineage) that maintain the authorized transmission of its Sufism doctrines up to its original shaykh (Sufi director, murshid). For the three shalawat groups, their silsilah ends up in a spiritual figure of Mbah Tamyiz, known and believed by his followers as wali mastur (hidden saint).

Another distinctive character of these three groups is the strict adherence to Sunni Sufism tradition as outlined by Junayd of Baghdad. The manifestation of this Sufism practice is absent from other urban Sufism groups. The tradition of "Junaydian" asserts that being a mystic means acting like Sufis which is achieved through long and hard spiritual journey, especially for selected disciples. Practicing Sufism means experiencing hard life, hunger, being object of scorn and ridicule, and constant fear. In contrast, practicing Sufism is not in the form of theoretical discourse about hunger, sincerity, and poverty. The whole process of "experiencing" is framed under the framework of the absolute obedience of murid (disciple) to the shaykh, murshid. For the thee shalawat groups, the essence of Sufism is obeying all the instructions of the murshid, because disciples consider themselves as corpse before their master. This "experiencing" Sufism is only displayed in the three majelis shalawats; no other urban Sufism groups displays similar features.

In addition, the articulation of rabitab doctrine in these three majelis shalawats is different from conventional tariqabs. These three groups transmit the doctrine of räbitah bi al-suḅbah and räbitab bi al-ghayb as an integral part in the process of spiritual strive through lelaku tirakat based on the instruction of the shaykh that is called as rabithah al'amaliyah (action-based connectedness). Meanwhile, in conventional Sufi order, rabitab is mostly related to dhikr and awräd which have been predetermined in the effort to achieve spiritual passing away of individual self in God. Concurrently, other groups of dhikr and shalawat hardly touch the doctrine. This description allows important proposition that the doctrines and practices of Sufim in Majelis Shalawat Kubro, Majelis Shalawat Muhammad, and Majelis Shalawat Adlimiyah is more than pseudo-Sufi order. Instead, they are new pseudo Sufi order because of their distinctive characters in the aspects of genealogy, transmission, and spiritual journey. This distinctiveness is absent from any other dhiker and shalawat groups as well as from conventional Sufi orders. [] 


\section{References}

al-Ajam, Rafiq. Mu'jam Musthalahat al-Tashawnuf al-Islami. Beirut: Maktabah Libnan Nasyirun, 1999.

al-Anshari, Abu Yahya Zakariyya Ibnu Muhammad. Ibkam al-Dilalah 'ala Tahrir al-Risalah al-Qusiariyyah, Vol. 1. Damascus: Dar alNu'man li al-Ulum, 2000.

al-Arusi, Musthafa. Hasyiyah al-'Allamah Musthafa al-Arusi al-Musamma Nata'ij al-Ifkar al-Qudsiyyah fi Bayan Ma'ani Syarkh al-Risalab alQusyairiyah, Vol. 1. Beirut: Dar al-Kutub al-Ilmiyyah, 2007.

al-Ghazali, Abu Hamid. Ayyuha al-Walad finasibat al-Muta'allimin wa Mawidatibim li Ya'lam wa Yumayyiz. Tlman Nafi'an. Singapore: alHaramain, 2005.

al-Khalidi, Muhammad al-Khani. Al-Sa'adah al-Abadiyah fima Ja'a bibi alNaqsyabandiyah. Istanbul: Maktabah al-Haqiqah, 2012.

al-Makki, Ahmad Syihabuddin bin Hajar al-Haitami. al-Fatawa alHaditsiyah. Beirut: Dar al-Fikr, 2013.

al-Naqsyabandi, Al-Khalid. "Risalah ila Khulafa'ihi fi Istanbul li Bayani Ma'na al-Rabithah al-Naqsyabandiyah," Nazar Abadzah (ed). Al-Syaikh al-Khalid al-Naqsyabandi, Al-Alim al-Mujaddid, Hayatubu wa Ahammu Mu'allafatibi. Beirut: Dar al-Fikr al-Mu'ashir, 1994.

al-Qusyairi, Abu al-Qasim Abdul Karim bin Hawazan. Al-Risalah alQusyairiyah. Beirut: Dar al-Kutub al-Ilmiyah, 2001.

al-Sya'rani, Abdul Wahhab, Al-Anwar fi Adabi al-Shubbah inda al-Akhyar. Damaskus: Maktabah Abu Ayyub al-Anshari, 2007.

al-Zarnuji, Burhan al-Islam. Ta'lim al-Muta'allim: 'alā Tariq al-Ta'allum. Beirut: Darul Ihya' al-Kutub al-'Arabiyah, n.d.

Asy'ari, KH. Hasyim. Adab al-Alim wa al-Muta'allim fi ma Yabtaj Ilaibi alMuta'allim fi Ihwali al-Ta'lim wa ma Yawaqqafu Ilaibi. Jombang: Maktabah al-Turast al-Islami, 1938.

Bad'iyyah, Muhammad Abdul. Al-Naqsyabandiyah, Nasy'atuba wa Tathawwuruba Lada al-Turk. Cairo: Dar al-Tsaqafiyah li al-Nasyar, 2010. 
Bazzano, Elliot and Marcia Hermansen. "Introduction." Elliot Bazzano and Marcia Hermansen (eds). Varieties of Sufism in America, Islam, Sufi Orders, and Authority in A Time of Transition. New York: State University of New York, 2020.

Bowen, Patrick D. History of Convertion to Islam in the United States, Vol. 1. Leiden: Brill, 2015.

Darniqah. al-Thariqah al-Naqsyabandiyah wa A'lamuba. Libya: Mathba'ah Jarus Bar, 1987.

Dewan Pimpinan Pusat Penyiaran Shalawat Wahidiyah. Profil Wahidiyah. Jombang: Dewan Pimpinan Pusat Penyiaran Shalawat Wahidiyah, n.d.

Dickson, William Rory. Living Sufism in North America, Between Tradition and Transformation. New York: The State University of New York, 2015.

Fathullah, Muhammad Amin al-Kurdi al-Irbili Ibnu al-Syaikh. Tanwir al-Qulub fi Mu'alati Allamu al-Ghuyub. Damascus: Mathaba'ah alShabah, 1991.

Howell, Julia Day. "'Calling' and 'Training': Role Innovation and Religious De-differentiation in Commercialised Indonesian Islam." Journal of Contemporary Religion 28, 3 (2013).

-. "Modernity and Islamic Spirituality in Indonesia's New Sufi Networks." Martin Van Bruinessen and Julia Day Howell (eds). Sufism and The 'Modern' in Islam. New York: I.B.Tauris, 2007.

--------. "Sufism and the Indonesian Islamic Revival." The Journal of Asian Studies 60, 3 (2001).

---------. "Sufism on the Silver Screen, Indonesian Innovations in Islamic Televangelism." Journal of Indonesian Islam 2, 2 (2008).

---------. Indonesia's Salafist Sufis. Singapore: S. Rajaratnam School of International Studies, 2009.

Huda, Sokhi. Kuliah Wahidiyah. Jombang: Dewan Pimpinan Pusat Penyiar Shalawat Wahidiyah, 2005.

---------. Tasawuf Kultural, Fenomena Shalawat Wahidiyah. Yogjakarta: LKiS, 2008. 
Ibad, M.N. Drikir Agung Para Wali Allah, Sejarah Penyusunan Drikrul Ghafilin dan Fadhilah Bacaan-Bacaannya. Bantul: Pustaka Pesantren, 2012.

Ibni Arabi, Abu Bakar Muhyiddin Muhammad bin Ali bin Muhammad bin Ahmad bin Abdullah al-Khatimi al-Ma'ruf bi. Al-Futubat alMakkiyah, Vol. V. Beirut: Dar al-Fikr al-Arabi, 2011.

Jati, Wasisto Raharjo. "Sufisme Urban di Perkotaan: Konstruksi Keimanan Baru Kelas Menengah Muslim. Jurnal Kajian \& Pengembangan Managemen Dakwah 5, 2, December 2015.

Machmudi, Yon. Islamizing Indonesia: The Rise of Jamaah Tarbiyah and Prosperous Justice (PKS). Canbera: ANU Press, 2008.

Malik, Abdul. "Institusi Persaudaraan Sufi." Jumal El-harakah 8, 3 (2006).

Mas'ud, Abdurrahman. Dari Haramain ke Nusantara, Jejak Arsitek Intelektual Pesantren. Jakarta: Penerbit Kencana, 2006.

Mukani. Dinamika Pendidikan Islam. Malang: Madani, 2016.

Muzakki, Akh. Islamic Televangelism in Changing Indonesia: Transmission, Authority, and The Politic of Ideas. Singapore: ISEAS, 2012.

Rachman, Saiful. Surat Kepada Anjing Hitam, Biografi dan Karomah Kiai Kholil. Jakarta: Pustaka Ciganjur, 2011.

Rahmawati. "Memahami Ajaran Fana', Baqa', dan Ittihad dalam Tasawuf." Al-Munzir 7, 2 (2014).

Schmidt, Garbi. Islam in Urban America, Sunni Muslim in Chicago. Philadelphia: Temple University Press, 2004.

Smith, Bianca J. and Saipul Hamdi, "Between and Salafi Subjects: Female Leadership, Spiritual Power and Gender Matters in Lombok." Bianca J. Smith and Mark Woodward (eds). Gender and Power in Indonesian Islam, Leaders, Feminists, and Pesantren Selves. London: Routledge, 2017.

Sujamto. Reorientasi dan Revitalisasi Pandangan Hidup Jawa. Semarang: Dhahara Press, 2000. 
Rubaidi

Zamhari, Arif. "Socio-Cultural Innovations in Urban Sufism, The Case Study of Majelis Dzikir and Shalawat Nurul Musthafa." Journal of Indonesian Islam 7, 1 (2013).

-. Rituals of Islamic Spirituality: A Study of Majlis Dhikr Groups in East Java. Canberra: The Australian National University, 2010. . and Julia Day Howell. "Taking Sufism to the Streets: Majelis Zikir and Majelis Salawat as New Venues for Popular Islamic Piety in Indonesia." Review of Indonesian and Malaysian Affairs 46, 2 (2012). 